\title{
Biomarkers in Nereis diversicolor (Polychaeta: Nereididae) as management tools for environmental assessment on the southwest Iberian coast
}

\author{
TÂNIA GOMES ${ }^{1}$, MARIA GONZALEZ-REY ${ }^{1}$, ARACELI RODRÍGUEZ-ROMERO ${ }^{2}$, \\ CHIARA TROMBINI ${ }^{2}$, IMMACULADA RIBA ${ }^{2}$, JULIÁN BLASCO $^{2}$ \\ and MARIA JOÃO BEBIANNO ${ }^{1}$ \\ ${ }^{1}$ CIMA, Faculty of Science and Technology, University of Algarve, Campus de Gambelas 8005-137 Faro, Portugal.
E-mail: mbebian@ualg.pt \\ ${ }^{2}$ Instituto de Ciencias Marinas de Andalucía, CSIC, Campus Río San Pedro, 11510 Puerto Real, Cádiz, Spain.
}

SUMMARY: The environmental quality of the southwest Iberian coast was assessed in different areas (Ria Formosa Lagoon, Guadiana Estuary and Cádiz Bay) focusing on metal contamination $(\mathrm{Cd}, \mathrm{Cu}, \mathrm{Ni}, \mathrm{Pb}$ and $\mathrm{Zn})$ in Nereis diversicolor whole tissues. In addition, associated toxicological effects were assessed using a multibiomarker approach combining several conventional biomarkers. The set of biomarkers selected included antioxidant enzymes (catalase, superoxide dismutase and glutathione peroxidase), metallothionein and lipid peroxidation. $N$. diversicolor from the Ria Formosa Lagoon, Guadiana River and Cádiz Bay responded differently to metal contamination with different biomarker responses showing a clear site trend, suggesting different sources and/or magnitudes of contamination. Cadmium was a source of oxidative stress in polychaetes, mainly in Cádiz Bay, with a significant influence on antioxidant enzymes and enhancement of lipid peroxidation. The highest MT concentrations were in the Ria Formosa Lagoon and in the Guadiana River, where there was a direct relationship with high nickel concentrations. Biomarker responses of $N$. diversicolor are useful tools for environmental quality assessment on the southwest Iberian coast, and more specific metal biomarkers should be included in future assessments.

Keywords: biomarkers, metals, Nereis diversicolor, antioxidant enzymes, metallothionein, lipid peroxidation, southwest Iberian coast.

RESUMEN: Biomarcadores en Nereis Diversicolor (Polychaeta: Nereididae) como herramientas de gestión de la EVAluación Del medio ambiente en el suroeste de la Península IBÉricA. - El estudio de la calidad ambiental de los ecosistemas costeros del SO de la Península Ibérica (Ría Formosa, estuario del Guadiana y bahía de Cádiz) en relación a la contaminación metálica $(\mathrm{Cd}, \mathrm{Cu}, \mathrm{Ni}, \mathrm{Pb}$ y $\mathrm{Zn}$ ) se ha llevado a cabo mediante el análisis del contenido de metales en Nereis diversicolor. Además, los efectos ecotoxicológicos fueron evaluados mediante una aproximación "multibiomarcadores", en donde se combinan varios biomarcadores convencionales. La batería de biomarcadores seleccionadas han sido: las enzimas antioxidantes (catalasa (CAT), superóxido dismutasa (SOD) y glutatión peroxidasa (GPX), metalotioneína (MT) y peroxidación lipídica (LPO). Los ejemplares de $N$. diversicolor recolectados en las distintas zonas, mostraron una respuesta diferente a la contaminación metálica, lo que sugiere diferentes fuentes y/o magnitud de la contaminación. Los niveles de cadmio estan directamente relacionados con las actividades SOD y CAT y los niveles de LPO. En el caso del níquel, sus niveles se hallaban correlacionados positivamente con los de MT en la Ría Formosa y en el río Guadiana. La integración de las respuesta de los biomarcadores en $N$. diversicolor ha demostrado ser una herramienta útil para la evaluación de la calidad ambiental de los ecosistemas costeros del SO de la Península Ibérica.

Palabras clave: biomarcadores, metales, Nereis diversicolor, enzimas antioxidantes, metalotioneínas, peroxidación lipídica, Suroeste Península Ibérica. 


\section{INTRODUCTION}

Estuaries are among the aquatic ecosystems most susceptible to the continuous influx of heterogeneous contaminant mixtures largely associated with nearby agricultural and/or industrial activities (Kennish 2002, Berthet et al. 2003). This leads irrevocably to a high inherent environmental risk because estuaries and related saltmarshes are key habitats for many ecologically relevant species, such as the endobenthic polychaete Nereis/Hediste diversicolor (Zhou et al. 2003, Durou et al. 2007a, Gillet et al. 2008). These quite abundant omnivorous organisms dwell in the sediment (often regarded as a long-term reservoir of contaminants), being crucial species not only due to the important role they play in the food web but also due to the remobilization of contaminant and nutrient loads linked to their burrowing and dietary behaviour (Amiard et al. 2007, Durou et al. 2007a,b, Gillet et al. 2008). These features confer to $N$. diversicolor its resistance and consequent ability to inhabit metal-rich sediments, and thus its importance as a bioindicator of estuarine environmental quality (Moreira et al. 2006, Poirier et al. 2006, Durou et al. 2008, Gillet et al. 2008, Solé et al. 2009).

Metals present at high concentrations induce deleterious effects in aquatic organisms, such as oxidative stress, because they enhance reactive oxygen species (ROS) production (Winston and Di Giulio 1991, Livingstone 2001). These effects are often assessed by analysing certain metal detoxification mechanisms where metallothioneins (MTs) assume an important role because they show both the ability to bind or form an inactive complex with certain metals favouring their storage or excretion as well as recognized oxyradical scavenger properties (Langston et al. 1998, Viarengo et al. 1999). Moreover, toxic metal-induced ROS are also counteracted by the action of an antioxidant enzyme cascade initiated by superoxide dismutase (SOD) activity that converts the highly reactive superoxide anion $\left(\mathrm{O}_{2}^{-}\right)$into hydrogen peroxide $\left(\mathrm{H}_{2} \mathrm{O}_{2}\right)$, which in turn is transformed by both catalase (CAT) and glutathione peroxidase (GPX) in water and oxygen. Lipid peroxidation (LPO) is associated with an over presence of ROS due to antioxidant defences system failure. The formation of lipid peroxides is characterized by the presence of a by-product: malondialdehyde (MDA) and hydroxyalkenals that is considered a useful damage biomarker (Winston and Di Giulio 1991, Livingstone 2001).

The aim of this study is to assess metal contamination at several sites of the southwest Iberian coast through metal analysis of $N$. diversicolor whole tissues, namely $\mathrm{Cd}, \mathrm{Cu}, \mathrm{Ni}, \mathrm{Pb}$ and $\mathrm{Zn}$. In addition, associated ecotoxicological effects and seasonal and spatial trends were determined using a multibiomarker approach including antioxidant enzymatic activities alterations, metallothionein and lipid peroxidation levels. The overview given by this study provides useful complementary data for environmental quality assessment.

\section{MATERIAL AND METHODS}

\section{Study Area}

The Ria Formosa Lagoon is a shallow, mesotidal lagoon system that is highly productive and dynamic, with high nutrient concentrations and constant water renewal (Mudge and Bebianno 1997, Dionísio et al. 1999). In recent years the water quality in the lagoon has deteriorated due to unsustainable economic development with a consequent decrease in bivalve production (Bebianno 1995, Coelho et al. 2002).

The Guadiana River is the fourth most important river of the Iberian Peninsula, located along the southern border between Portugal and Spain. Several point and diffuse pollution sources affect the quality of the Guadiana waters, originating from urban centres, industry, landfills, cattle breeding, and olive and vineyard crops. The intensive agricultural activities and pesticide treatments carried out in the Spanish areas close to the hydrological basin of the river also influence the discharges into the river (Cravo et al. 2006, Almeida et al. 2007).

The Bay of Cádiz is a littoral ecosystem that covers four different regions: the outer bay, which has oceanic characteristics (wave, wind and tide action); the inner bay, which is strongly influenced by tides; the amphibious bay, which has a rich and varied ecosystem, including tidal marshes; and the terrestrial bay, which is permanently emerged. These areas have intense maritime traffic and have supported decades of industrial activities related to naval construction (Blasco et al. 2000, 2010, Carrasco et al. 2003).

\section{Sampling}

$N$. diversicolor were collected during two seasonal campaigns, at the end of autumn (2006) and spring (2007). Sampling sites with different contamination levels were chosen in the Ria Formosa Lagoon and Cádiz Bay (Fig. 1). Due to constraints on polychaete abundances, in autumn individuals were collected at only one site in the Ria Formosa Lagoon, Faro (F-RF), while in spring two other sites were chosen, Ramalhete (R-RF) and Ribeira de Almargem (A-RF). In the Guadiana River (GD), sampling was only possible in spring. In Cádiz Bay, three sites were chosen for the autumn and spring campaigns: Puente Zuazo (PZ), Trocadero (TR) and Rio San Pedro (RSP). After collection, the polychaetes were transported alive to the laboratory in cool boxes filled with sediment and covered with seawater from the site of origin. At the laboratory, polychaetes were cleaned to eliminate sediment residues, frozen in liquid nitrogen and stored at $-80^{\circ} \mathrm{C}$ until analysis.

\section{Metal analysis}

Cadmium, copper, nickel, lead and zinc concentrations were determined in dried $\left(80^{\circ} \mathrm{C}\right)$ subsamples 

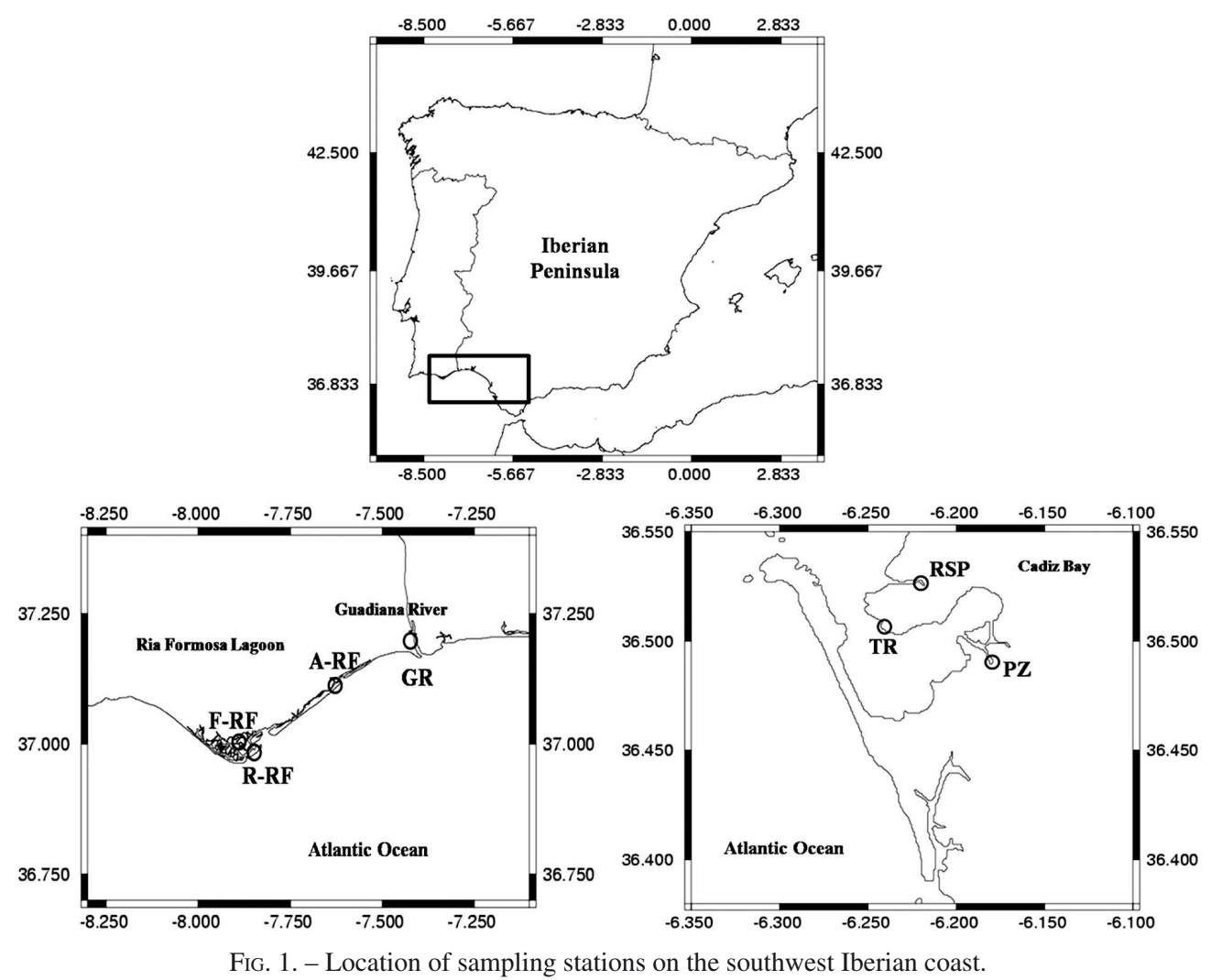

of the homogenate of the total tissue of the polychaetes. Samples were submitted to a wet digestion with concentrated nitric acid $\left(\mathrm{HNO}_{3}\right)$. Analyses were performed by atomic absorption spectrophotometry, using standard addition methods. The analytical procedure was checked using a standard reference material (Lobster Hepatopancreas) provided by the National Research Council, Canada - TORT II. The values (mean \pm standard deviation) obtained were $27.21 \pm 0.88$ $\mu \mathrm{g} \mathrm{g}^{-1}$ for $\mathrm{Cd}, 106.54 \pm 1.81 \mu \mathrm{g} \mathrm{g}^{-1}$ for $\mathrm{Cu}, 2.31 \pm 0.08$ $\mu \mathrm{g} \mathrm{g}^{-1}$ for $\mathrm{Ni}, 0.30 \pm 0.02 \mu \mathrm{g} \mathrm{g}^{-1}$ for $\mathrm{Pb}$ and $193.66 \pm 7.13$ $\mu \mathrm{g} \mathrm{g}^{-1}$ for $\mathrm{Zn}$ compared with the certificated values of $26.7 \pm 0.6 \mu \mathrm{g} \mathrm{g}^{-1}, 106.0 \pm 10.0 \mu \mathrm{g} \mathrm{g}^{-1}, 2.50 \pm 0.19 \mu \mathrm{g} \mathrm{g}^{-1}$, $0.35 \pm 0.13 \mu \mathrm{g} \mathrm{g}^{-1}$ and $180.0 \pm 6.0 \mu \mathrm{g} \mathrm{g}^{-1}$ respectively. All metal concentrations are expressed on a dry tissue weight basis.

\section{Antioxidant enzymes}

To determine the levels of enzymatic activities, total tissues of Nereis diversicolor were homogenized in $20 \mathrm{mM}$ Tris- $\mathrm{HCl}$ buffer, $\mathrm{pH} 7.6$, containing $1 \mathrm{mM}$ of EDTA, $0.5 \mathrm{M}$ of saccharose, $0.15 \mathrm{M}$ of $\mathrm{KCl}$ and 1 $\mathrm{mM}$ of DTT. The homogenates were centrifuged at 500 $g$ for 15 minutes at $4^{\circ} \mathrm{C}$ to precipitate large particles and re-centrifuged at $12000 \mathrm{~g}$ for 45 minutes at $4^{\circ} \mathrm{C}$ to precipitate the mitochondrial fraction. The cytosolic fraction was purified on a Sephadex G-25 gel column (PD10, Pharmacia) to remove low molecular weight proteins. All enzymatic activities were determined in the cytosolic fraction.
Superoxide dismutase activity (SOD, EC 1.15.1.1) was determined by measuring the reduction of cytochrome c by the xanthine oxidase/hypoxanthine system at $550 \mathrm{~nm}$. One unit of SOD is defined by the amount of the enzyme that inhibits $50 \%$ of the reduction of cytochrome c (McCord and Fridovich 1969). The SOD activity obtained is expressed as $\mathrm{U} \mathrm{mg}^{-1}$ of total protein concentration.

Catalase activity (CAT, EC 1.11.1.6) was measured following the method described by Greenwald (1985) as a result of the decrease in absorbance at $240 \mathrm{~nm}$ due to hydrogen peroxide consumption. The results are expressed as $\mu$ moles $\mathrm{min}^{-1} \mathrm{mg}^{-1}$ of total protein concentration.

Total glutathione peroxidase (GPX) was measured following NADPH oxidation at $340 \mathrm{~nm}$ in the presence of excess glutathione reductase, reduced glutathione and cumene hydroperoxide as substrate (Lawrence and Burk 1976). GPX activities are expressed in nmoles $\mathrm{min}^{-1} \mathrm{mg}^{-1}$ of total protein concentration.

\section{Metallothionein analysis}

Metallothionein (MT) was quantified in the total tissues of polychaetes. Samples were homogenized in three volumes of Tris- $\mathrm{HCl}$ buffer $(0.02 \mathrm{M} \mathrm{pH}$ 8.6) in an ice bath. An aliquot of the homogenate was used for metal analysis. A further aliquot of the homogenate was centrifuged at $30000 \mathrm{~g}$ for 45 minutes at $4^{\circ} \mathrm{C}$. The supernatant was separated from the pellet and two aliquots were used for lipid peroxidation and total 
protein determination. The remaining supernatant was heat-treated at $80^{\circ} \mathrm{C}$ for $10 \mathrm{~min}$ to precipitate the high molecular weight proteins and re-centrifuged at 30000 $\mathrm{g}$ for 45 minutes at $4^{\circ} \mathrm{C}$. Aliquots of the heat-treated cytosol were used to quantify the MT concentration using differential pulse polarography according to the method developed by Bebianno and Langston (1989). In the absence of a polychaete MT standard, quantification of the MT in the cytosol was based on rabbit liver metallothionein, MT-I, using the method of standard additions. MT concentrations were determined as a milligram per gram of total protein concentration.

\section{Lipid peroxidation analysis}

Lipid peroxidation (LPO) was assessed by determining malondialdehyde (MDA) and 4-hydroxyalkenals (4-HNE) concentrations upon decomposition by polyunsaturated fatty acid peroxides, following the method described by Erdelmeier et al. (1998). This procedure is based on the reaction of two moles of $N$ methyl-2-phenylindole, a chromogenic reagent, with one mole of either MDA or $4-\mathrm{HNE}$ at $45^{\circ} \mathrm{C}$ for 60 min to yield a stable chromophore that has maximum absorbance at $586 \mathrm{~nm}$, using malondialdehyde bis(tetrametoxypropan) as a standard. Lipid peroxidation is expressed as $\mu$ mols of MDA and 4-HNE per gram of total protein concentration.

\section{Total protein analysis}

The total protein content of the cytosolic fractions of $N$. diversicolor was measured with the Lowry method (Lowry et al. 1951) using Folin's Reagent and Bovine Serum Albumin (BSA) as reference standard materials.

\section{Statistical analysis}

The data obtained was tested for normality and homogeneity of variances to determine whether they satisfy the assumptions associated with parametric tests, and one-way analysis of variance (ANOVA) or the Kruskal-Wallis were applied. The Tukey (parametric data) or the Dunn's tests (non-parametric data) were used to discriminate significant differences. Pearson's correlation analysis was applied between biomarkers and metals to verify existing relationships. Canonical Correspondence Analysis (CCA) was used to assess the
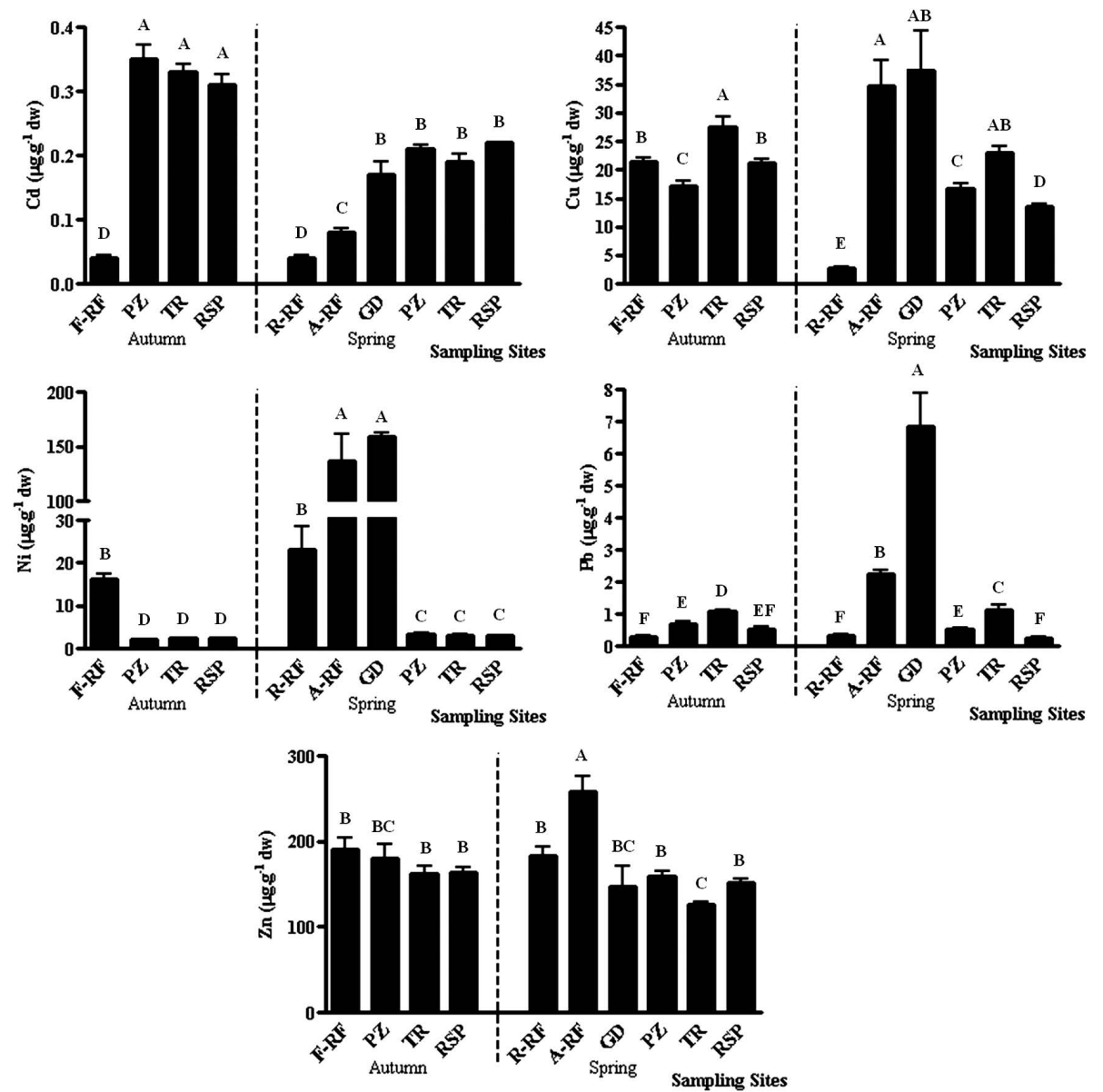

FIG. 2. - Concentrations of cadmium, copper, nickel, lead and zinc ( $\mu \mathrm{g} \mathrm{g}^{-1}$ dry weight) in polychaete tissues collected at the sampling sites along the southwest Iberian coast in autumn and spring (mean \pm std). Different letters represent significant differences among sampling locations in autumn and spring, at $p<0.05$ using Tukey or Dunn's post hoc tests. 
TABLE 1. - Nereis diversicolor biomarker levels (mean $\pm \mathrm{sd}$ ) in the southwest Iberian Peninsula in the two seasonal periods. Different letters represent significant differences among sampling locations in autumn and spring, at $p<0.05$ using Tukey or Dunn's post hoc tests. TP - total protein levels. F-RF: Faro, Ria Formosa Lagoon; PZ: Puente Zuazo, Cádiz Bay; TR: Trocadero, Cádiz Bay; RSP: Rio San Pedro, Cádiz Bay; R-RF: Ramalhete, Ria Formosa Lagoon; A-RF: Ribeira de Almargem, Ria Formosa Lagoon; GD: Guadiana River.

\begin{tabular}{|c|c|c|c|c|c|c|}
\hline Season & Location & $\begin{array}{c}\mathrm{SOD} \\
\left(\mathrm{U} \mathrm{mg}^{-1} \mathrm{TP}\right)\end{array}$ & 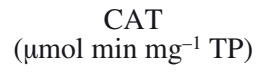 & $\begin{array}{c}\text { GPX-T } \\
\left(\text { nmol min } \mathrm{mg}^{-1} \mathrm{TP}\right)\end{array}$ & $\begin{array}{c}\mathrm{MT} \\
\left(\mathrm{mg} \mathrm{g}^{-1} \mathrm{TP}\right)\end{array}$ & $\begin{array}{c}\text { LPO } \\
\left(\mu \mathrm{mol} . \mathrm{g}^{-1} \mathrm{TP}\right)\end{array}$ \\
\hline \multirow[t]{4}{*}{ Autumn } & $\mathrm{F}-\mathrm{RF}$ & $9.4 \pm 2.4^{\mathrm{e}}$ & $45.8 \pm 13.9^{d}$ & $12.0 \pm 1.0^{\mathrm{bc}}$ & $3.1 \pm 0.3^{\mathrm{bc}}$ & $0.3 \pm 0.0^{\mathrm{e}}$ \\
\hline & $\mathrm{PZ}$ & $34.2 \pm 4.3^{\mathrm{b}}$ & $83.5 \pm 19.6^{\mathrm{ab}}$ & $16.2 \pm 4.1^{b}$ & $1.0 \pm 0.3^{\mathrm{d}}$ & $1.6 \pm 0.4^{b}$ \\
\hline & $\mathrm{TR}$ & $54.6 \pm 14.2^{\mathrm{a}}$ & $95.3 \pm 33.2^{\mathrm{ab}}$ & $19.1 \pm 5.0^{\mathrm{a}}$ & $3.4 \pm 0.9^{b}$ & $1.3 \pm 0.2^{\mathrm{bc}}$ \\
\hline & RSP & $48.9 \pm 9.9^{\mathrm{ab}}$ & $106.2 \pm 18.6^{\mathrm{ac}}$ & $17.5 \pm 4.8^{\mathrm{ab}}$ & $2.0 \pm 0.3^{c}$ & $1.0 \pm 0.2^{\mathrm{b}}$ \\
\hline \multirow[t]{6}{*}{ Spring } & R-RF & $13.3 \pm 2.0^{\mathrm{d}}$ & $67.8 \pm 11.3^{\mathrm{bc}}$ & $25.7 \pm 5.1^{\mathrm{a}}$ & $4.9 \pm 1.0^{\mathrm{a}}$ & $0.2 \pm 0.0^{\mathrm{e}}$ \\
\hline & A-RF & $12.9 \pm 2.6^{\mathrm{de}}$ & $43.7 \pm 7.5^{\mathrm{d}}$ & $13.2 \pm 2.5^{b}$ & $6.0 \pm 1.5^{\mathrm{a}}$ & $0.1 \pm 0.0^{f}$ \\
\hline & GD & $25.7 \pm 1.9^{c}$ & $32.7 \pm 2.5^{\mathrm{d}}$ & $10.0 \pm 2.3^{\mathrm{cd}}$ & $4.1 \pm 1.4^{\mathrm{ab}}$ & $0.4 \pm 0.1^{\mathrm{d}}$ \\
\hline & $\mathrm{PZ}$ & $45.4 \pm 11.5^{\mathrm{ab}}$ & $70.8 \pm 6.5^{\mathrm{bc}}$ & $7.6 \pm 1.7^{\mathrm{de}}$ & $3.0 \pm 0.7^{b c}$ & $2.5 \pm 0.2^{\mathrm{a}}$ \\
\hline & $\mathrm{TR}$ & $37.7 \pm 9.9^{a b c}$ & $74.7 \pm 24.8^{\mathrm{ac}}$ & $6.7 \pm 0.7^{\mathrm{e}}$ & $2.7 \pm 0.8^{b c}$ & $0.9 \pm 0.0^{c}$ \\
\hline & RSP & $34.9 \pm 11.0^{\mathrm{bc}}$ & $56.6 \pm 17.0^{\mathrm{cd}}$ & $5.3 \pm 0.5^{\mathrm{e}}$ & $2.5 \pm 0.7^{b c}$ & $1.0 \pm 0.2^{\mathrm{c}}$ \\
\hline
\end{tabular}

influence of biomarkers associated with metal levels on the different sites. Statistical significance was defined at the $p<0.05$ level. Statistical analyses were performed using XLSTAT ${ }^{\circledR} 2010$.

\section{RESULTS}

\section{Metal concentrations}

Metal $(\mathrm{Cd}, \mathrm{Cu}, \mathrm{Ni}, \mathrm{Pb}$ and $\mathrm{Zn})$ concentrations were determined in the whole tissues of $N$. diversicolor and are shown in Figure 2. Polychaetes from all the sites in Cádiz Bay had higher cadmium levels in autumn (1.8, 1.7 and 0.71 -fold, $p<0.05$ ) compared to spring. The highest concentrations were found in polychaetes from PZ, TR and RSP for both seasons, followed by the ones from Guadiana River $\left(0.17 \pm 0.04 \mu \mathrm{g} \mathrm{g}^{-1}\right.$ d.w. $)$. The lowest concentrations were detected in the Ria Formosa Lagoon, with the minimum levels in F-RF in autumn $\left(0.04 \pm 0.01 \mu \mathrm{g} \mathrm{g}^{-1}\right.$ d.w. $)$ and R-RF in spring $(0.04 \pm 0.01$ $\mu \mathrm{g} \mathrm{g} \mathrm{g}^{-1}$ d.w.).

$N$. diversicolor from the Rio San Pedro (RSP) were the only ones with significant differences in $\mathrm{Cu}$ concentrations between seasons $\left(21.17 \pm 1.20 \mu \mathrm{g} \mathrm{g}^{-1} \mathrm{~d} . \mathrm{w}\right.$. in autumn and $13.64 \pm 0.47 \mu \mathrm{g} \mathrm{g}^{-1} \mathrm{~d}$.w. in spring, $\mathrm{p}<0.05$ ). The highest levels of $\mathrm{Cu}$ were detected in polychaetes from GD and A-RF in spring and TR in autumn and spring, ranging from $37.47 \pm 11.88 \mu \mathrm{g} \mathrm{g}^{-1}$ d.w. in GD to $23.08 \pm 1.93 \mu \mathrm{g} \mathrm{g}^{-1} \mathrm{~d}$.w. in TR in spring. The lowest concentrations were detected in polychaetes from RSP $\left(13.64 \pm 0.47 \mu \mathrm{g} \mathrm{g}^{-1}\right.$ d.w.) and R-RF $\left(2.66 \pm 0.65 \mu \mathrm{g} \mathrm{g}^{-1}\right.$ d.w.) in spring.

Polychaetes from all the sites in Cádiz Bay had higher nickel concentrations in spring than in autumn $(1.7,1.3$ and 1.2-fold, $p<0.05)$. The highest $\mathrm{Ni}$ concentrations were detected in polychaetes from the Guadiana River (159.30 $\pm 6.13 \mu \mathrm{g} \mathrm{g}^{-1}$ d.w.) and A-RF $\left(136.75 \pm 41.65 \mu \mathrm{g} \mathrm{g}^{-1}\right.$ d.w.), followed by the individuals from the F-RF and R-RF $\left(16.13 \pm 2.89 \mu \mathrm{g} \mathrm{g}{ }^{-1}\right.$ d.w. and $23.26 \pm 7.33 \mu \mathrm{g} \mathrm{g}^{-1} \mathrm{~d}$.w. respectively), all in the Ria Formosa Lagoon. The lowest levels were found in individuals from Cádiz Bay, ranging from $3.47 \pm 0.39 \mu \mathrm{g}$ $\mathrm{g}^{-1}$ d.w. in PZ in spring to $2.05 \pm 0.06 \mu \mathrm{g} \mathrm{g}^{-1}$ d.w. in PZ in autumn.
No differences were found for $\mathrm{Pb}$ levels in $N$. diversicolor between seasons except for those from TR, with a 1.1-fold increase in spring. The highest $\mathrm{Pb}$ concentration was found in the Guadiana River $(6.84 \pm 1.50$ $\mu \mathrm{g} \mathrm{g}^{-1}$ d.w.), followed by the A-RF in the Ria Formosa Lagoon $\left(2.23 \pm 0.24 \mu \mathrm{g} \mathrm{g}^{-1}\right.$ d.w.) in spring. The lowest concentrations were also detected in the Ria Formosa Lagoon, in F-RF in autumn $\left(0.30 \pm 0.05 \mu \mathrm{g} \mathrm{g}^{-1}\right.$ d.w. $)$ and R-RF in spring $\left(0.34 \pm 0.03 \mu \mathrm{g} \mathrm{g}^{-1}\right.$ d.w. $)$, and in Cádiz Bay in RSP in autumn $\left(0.54 \pm 0.14 \mu \mathrm{g} \mathrm{g}^{-1}\right.$ d.w. $)$ and spring $\left(0.23 \pm 0.08 \mu \mathrm{g} \mathrm{g}^{-1}\right.$ d.w. $)$.

Zinc concentrations in $N$. diversicolor from all sites were similar between seasons except for TR, where a higher $\mathrm{Zn}$ level was detected in spring (1.3-fold, $p<0.05)$. Zinc levels ranged between $257.50 \pm 37.41 \mu \mathrm{g}$ $\mathrm{g}^{-1}$ d.w. and $126.13 \pm 4.65 \mu \mathrm{g} \mathrm{g}^{-1}$ d.w. in A-RF and TR in spring respectively, with similar concentrations between the remaining sites $(\mathrm{p}>0.05)$.

There were several significant relationships between metal levels in $N$. diversicolor tissues, namely between $\mathrm{Cu}$ and $\mathrm{Ni}(\mathrm{r}=0.70, p<0.05), \mathrm{Cu}$ and $\mathrm{Pb}$ $(\mathrm{r}=0.72, p<0.05)$ and $\mathrm{Ni}$ and $\mathrm{Pb}(\mathrm{r}=0.86, p<0.01)$.

\section{Biomarkers}

The biomarkers analysed in $N$. diversicolor per site and sampling period are presented in Table 1 . There was no seasonal influence on the SOD activity of $N$. diversicolor. The highest SOD activities were detected in polychaetes from TR $\left(54.6 \pm 14.6 \mathrm{U} \mathrm{mg}^{-1} \mathrm{TP}\right)$ and RSP

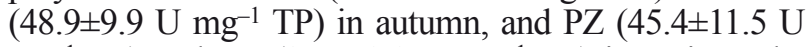
$\left.\mathrm{mg}^{-1} \mathrm{TP}\right)$ and TR (37.7 $\left.\pm 9.9 \mathrm{U} \mathrm{mg}^{-1} \mathrm{TP}\right)$ in spring. The lowest levels were found in polychaetes from the Ria Formosa Lagoon, namely F-RF $\left(9.4 \pm 2.4 \mathrm{U} \mathrm{mg}^{-1} \mathrm{TP}\right), \mathrm{A}-\mathrm{RF}$ $\left(12.9 \pm 2.6 \mathrm{U} \mathrm{mg}^{-1} \mathrm{TP}\right)$ and R-RF $\left(13.3 \pm 2.0 \mathrm{U} \mathrm{mg}^{-1} \mathrm{TP}\right)$, with no significant differences between them $(p>0.05)$.

A similar trend was found for CAT activity. The activities of this enzyme in $N$. diversicolor were similar between seasons for the Ria Formosa Lagoon and Cádiz Bay $(p>0.05)$. Levels ranged from 106.2 \pm 18.6

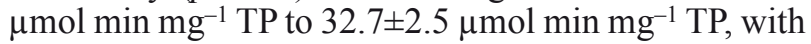
the highest values in polychaetes from Cádiz Bay in both seasons and the lowest values in F-RF in autumn and GD and A-RF in spring. 
For GPX, a seasonal variation was observed in polychaetes from PZ, TR and RSP, with a $0.53,0.65$ and 0.70 fold decrease, respectively, in autumn. The maximum levels were found both in spring in R-RF $\left(25.7 \pm 5.1 \mathrm{nmol} \mathrm{min} \mathrm{mg}^{-1} \mathrm{TP}\right)$ and autumn in TR and RSP $\left(19.1 \pm 5.0 \mathrm{nmol} \mathrm{min} \mathrm{mg}^{-1} \mathrm{TP}\right.$ and $17.5 \pm 4.8 \mathrm{nmol}$ min $\mathrm{mg}^{-1}$ TP respectively). The minimum activities were detected in polychaetes from Cádiz Bay in spring $\left(7.6 \pm 1.7 \mathrm{nmol} \mathrm{min} \mathrm{mg}^{-1} \mathrm{TP}\right.$ for PZ, $6.7 \pm 0.7 \mathrm{nmol} \mathrm{min}$ $\mathrm{mg}^{-1} \mathrm{TP}$ for TR and $5.3 \pm 0.5 \mathrm{nmol} \mathrm{min} \mathrm{mg}^{-1} \mathrm{TP}$ for RSP).

For MT, significant differences between autumn and spring were only found in polychaetes from $\mathrm{PZ}$, with a 3 -fold increase in spring. $N$. diversicolor from GD, A-RF and R-RF had the highest MT concentrations $(4.1 \pm 1.4$ $\mathrm{mg} \mathrm{g}^{-1} \mathrm{TP}, 6.0 \pm 1.5 \mathrm{mg} \mathrm{g}^{-1} \mathrm{TP}$ and $4.9 \pm 1.0 \mathrm{mg} \mathrm{g}^{-1} \mathrm{TP}$, respectively) and the lowest concentrations were found in those from PZ in autumn $\left(1.0 \pm 0.3 \mathrm{mg} \mathrm{g}^{-1} \mathrm{TP}\right)$.

Lipid peroxidation expressed as MDA and 4-HNE concentrations followed the same seasonal pattern as MT, that is, polychaetes from PZ had a higher concentration in spring $(1.56$-fold, $p<0.05)$. Lipid peroxidation was higher in $N$. diversicolor from $\mathrm{PZ}$ in spring $\left(2.5 \pm 0.2 \mu \mathrm{mol} \mathrm{g}^{-1} \mathrm{TP}\right)$, followed by those from PZ and TR in autumn $\left(1.6 \pm 0.4 \mu \mathrm{mol} \mathrm{g}^{-1} \mathrm{TP}\right.$ and $1.3 \pm 0.2 \mu \mathrm{mol}$ $\left.\mathrm{g}^{-1} \mathrm{TP}\right)$. The lowest levels were detected in polychaetes from the Ria Formosa Lagoon, ranging from $0.1 \pm 0.0$ $\mu \mathrm{mol} \mathrm{g}{ }^{-1} \mathrm{TP}$ in A-RF in spring to $0.3 \pm 0.0 \mu \mathrm{mol} \mathrm{g}^{-1} \mathrm{TP}$ in F-RF in autumn.

There were two significant relationships between biomarkers: SOD activity is directly related to CAT activity $(\mathrm{r}=0.75, p<0.05)$ and negatively to LPO $(\mathrm{r}=$ $0.74, p<0.05)$.

\section{Relationship between metals and biomarkers}

Multiple correlations were conducted to assess the relationships between metals in $N$. diversicolor whole tissues and biochemical responses. Cadmium and nickel were the only metals that showed a significant relationship with biomarker levels. $\mathrm{Cd}$ is directly related to SOD activity $(\mathrm{r}=0.88, p<0.01)$, CAT activity $(\mathrm{r}=0.73$, $p<0.05)$ and LPO levels $(\mathrm{r}=0.66, p<0.05)$. Nickel is directly related to $\mathrm{MT}(\mathrm{r}=0.68, p<0.05)$ and negatively to CAT ( $\mathrm{r}=-0.71, p<0.05)$.

Metal concentrations in the sediments from the same sites and collected at the same time (Blasco et al. 2010) were also included in the analysis due to the importance of metal transfer from ingested sediments to these species and to higher trophic levels (Coelho et al. 2008). Cadmium was the only metal with a significant relationship between its concentration in polychaete tissues and in sediments $(\mathrm{r}=0.69, p<0.05)$.

Canonical Correspondence Analysis (CCA) was applied to biomarkers and metal levels in polychaetes from the different sites to determine the factors that influence the variance of biomarkers (Fig. 3). The two main axes explain $94.67 \%$ of the total variance, where only PC1 represents $78.59 \%$. Polychaetes from the Ria Formosa Lagoon, Guadiana River and Cádiz

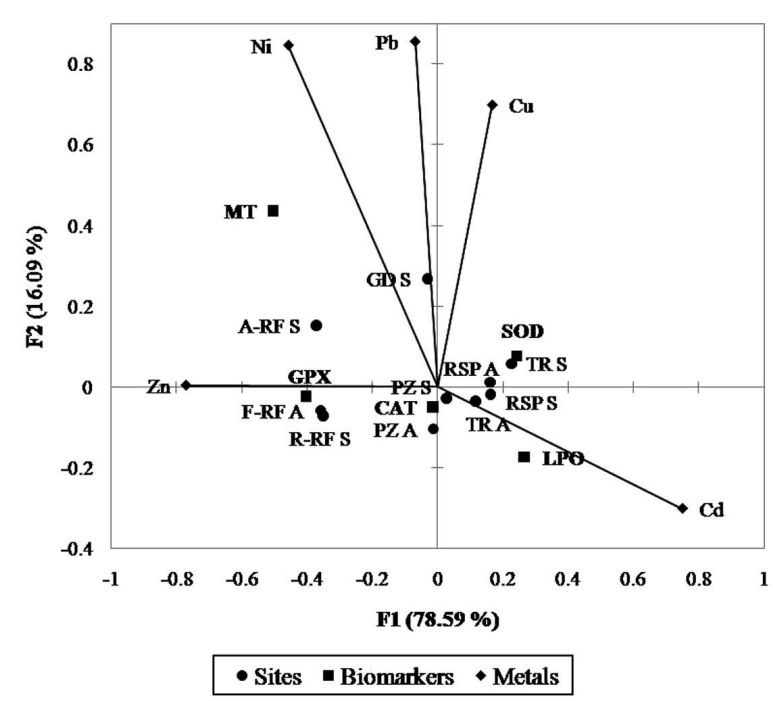

FIG. 3. - Canonical correspondence analysis (CCA) of the set of biomarkers and metal concentrations in the polychaete Nereis diversicolor collected at the sampling sites along the southwest Iberian coast in autumn and spring.

Bay responded differently to metal contamination with different biomarker responses, showing a clear site trend. The overall CCA shows a site related trend but no seasonal differentiation in biomarker responses. The sampling sites are clearly separated, with a close association between the three sites within Cádiz Bay (TR, PZ and RSP) as well as the three sites within the Ria Formosa Lagoon (F-RF, R-RF and A-RF). SOD and CAT activities are higher in Cádiz Bay in association with higher cadmium concentrations that are directly related to lipid peroxidation. In the Ria Formosa Lagoon, GPX responds primarily to the $\mathrm{Zn}$ concentration, most closely associated with R-RF. The highest MT concentrations are in the Ria Formosa Lagoon and in the Guadiana River, and are closely related to higher nickel concentrations. $\mathrm{Pb}$ is the main metal influencing polychaetes in the Guadiana River, while Ni is more associated with the Guadiana River and A-RF in spring.

\section{DISCUSSION}

The coastal ecosystems from the southwest Iberian Peninsula are strongly impacted by human activities. This anthropogenic pressure influences the structure and dynamics of the estuaries and saltmarshes of this area, mainly through mining, urban, agricultural and harbour effluents and discharges (Carrasco et al. 2003, Pérez et al. 2004, Almeida et al. 2007, Solé et al. 2009).

Considering the importance and potential complexity of aquatic pollution in estuaries, it is recommended to apply a multibiomarker approach in order to obtain a more comprehensive and integrated view of the biological responses, and complement the information given by chemical measures of contaminant contents in the selected species (Cajaraville et al. 2000, Sun and Zhou 2008, Cravo et al. 2009). 
Numerous environmental variables have the capacity to trigger the antioxidant defence system in polychaete species, such as solar radiance, hydrogen peroxide, salinity, water temperature, oxygen, and also exposure to several classes of contaminants (Bocchetti et al. 2004, Ait Alla et al. 2006, Moreira et al. 2006, Ferreira-Cravo et al. 2007, Sun and Zhou 2008, Douhri and Sayah 2009).

The overall metal concentrations determined in $N$. diversicolor tissues showed different spatial responses, reflecting different origins and intensities of contamination, but with no clear seasonal patterns. Guadiana River and Ria Formosa Lagoon are strongly influenced by metallic contamination with higher $\mathrm{Cu}, \mathrm{Ni}$ and $\mathrm{Pb}$ levels in $N$. diversicolor tissues compared to those from Cádiz Bay. Only cadmium was higher in polychaetes from Cádiz Bay. Both $\mathrm{Cu}$ and $\mathrm{Cd}$ are known to accumulate in $H$. diversicolor and other polychaete species proportionally to their concentration in the surrounding medium (Díez et al. 2000, Berthet et al. 2003, Poirier et al. 2006). The higher concentration of these two metals in these particular ecosystems is of anthropogenic origin associated with sewage and industrial effluents and agriculture runoffs (Bebianno 1995, Blasco et al. 2000, Carrasco et al. 2003, Caetano et al. 2006). Nickel is one of the trace-element constituents of the sediments of the south coast of Portugal and one of the major input sources of this metal is land runoff due to rainfall (Boski et al. 1999, Machado et al. 1999). The polychaetes in Guadiana River exhibited the highest lead levels. The presence of $\mathrm{Pb}$ in this river is related to its location within the Iberian Pyrite Belt, where the untreated mine wastes and discharges of acid mine waters represent the two major sources of this metal. Concurrently, industrial activities, sewage waste and remains of leaded petrol are considered additional $\mathrm{Pb}$ inputs (Caetano et al. 2006, Company et al. 2008, 2011, Kalman et al. 2008). The strong influence of $\mathrm{Pb}$ in polychaetes from the Guadiana River was also supported by the CCA; however, this was not particularly associated with any of the biomarkers selected. As an essential metal used as a co-factor in numerous enzymes, Zn concentrations in marine organisms can be regulated, as in N. diversicolor (Bocchetti et al. 2004, Wang and Rainbow 2005, Durou et al. 2007a,b). In the present study no significant enhancement or differences between sites were detected in $\mathrm{Zn}$ concentration in $N$. diversicolor tissues despite the high anthropogenicderived metal concentrations in the sediments, which is in agreement with previous studies (Berthet et al. 2003, Carrasco et al. 2003, Blasco et al. 2010).

The metal concentrations detected are characteristic of low or moderate levels of contamination (see levels in sediments from the same sites) (Blasco et al. 2010). Overall, metal concentrations in $N$. diversicolor tissues are in the same range of those reported in Cádiz Bay in previous years (Solé et al. 2009). Several industries that use metals have developed in recent years in the areas within the bay, namely manufacturers of car and aircraft components, which have resulted in a continuous input of metals into the bay (Blasco et al. 2000, 2010, Carrasco et al. 2003). For the other sites, the only metal concentrations in the literature are from bivalve species that are not directly comparable to polychaetes. Nevertheless, Blasco et al. (2010) reported that metals in sediments from the Ria Formosa Lagoon and Guadiana River are also in agreement with previous studies, indicating similar levels of contamination (Bebianno 1995, Caetano et al. 2006).

The possible effects that sediment-based metals can have on aquatic organisms living in sediments depend on the bioavailability of the metals (Díez et al. 2000, Berthet et al. 2003). As for the metal contents in sediments, $\mathrm{Cd}$ concentrations are directly reflected in polychaete tissues, as corroborated by the correlation analysis. Cadmium in sediments from all sites appears to have high availability to polychaetes. $N$. diversicolor is a good indicator of $\mathrm{Ag}, \mathrm{Cd}, \mathrm{Co}, \mathrm{Cr}, \mathrm{Cu}$ and $\mathrm{Pb}$ concentrations, reflecting metal bioavailabilities in this compartment (Díez et al. 2000, Berthet et al. 2003, Poirier et al. 2006).

Metals are able to produce ROS through redox cycling by depleting glutathione and protein-bound sulphydryl groups $(\mathrm{Cd}, \mathrm{Cu}, \mathrm{Hg}, \mathrm{Ni}$ and $\mathrm{Pb})$ and inhibiting some antioxidant enzymes, among others (Wang and Rainbow 2005, Moreira et al. 2006, Valavanidis et al. 2006). In this study, polychaetes antioxidant efficiency was assessed by analysing antioxidant enzymes (SOD, CAT and GPX). These enzymes responded efficiently to metal contamination, allowing site differentiation but no seasonal discrimination. SOD, CAT and GPX had similar patterns with higher activities in organisms from Cádiz Bay compared to those from the Ria Formosa Lagoon and Guadiana River. These antioxidant enzymes were activated due to the presence of high metal concentrations, principally cadmium. A metal pollution gradient exist at these sites, that includes discharges from domestic sources, offshore industries and shipbuilding, in which the presence of cadmium is a recent input into the bay with a high bioavailability from sediments (Pérez et al. 2004, Solé et al. 2009, Blasco et al. 2010). Several studies have reported the enhancement of antioxidant enzyme activities in polychaetes to cope with metal stress both in laboratory exposures and in the field (e.g. $\mathrm{Cd}, \mathrm{Cu}$ ) (Geracitano et al. 2004, Bocchetti et al. 2004, FerreiraCravo et al. 2007, Sun and Zhou 2008, Douhri and Sayah 2009). This result is confirmed by the statistical analyses, which showed a significant relationship between the $\mathrm{Cd}$ concentrations and SOD and CAT activities in polychaete tissues associated with the sites within Cádiz Bay. CAT and SOD are therefore linked to counteract ROS production originated by the high $\mathrm{Cd}$ concentrations found within the bay. Catalase is also associated with $\mathrm{Ni}$, as high concentrations of this metal inhibit CAT enzymatic activity. As for GPX, the CCA analysis showed an association between $\mathrm{Zn}$ concentration and GPX activities in polychaetes from the Ria Formosa Lagoon; however, the relationship was not significant. 
TABLE 2. - Biomarker levels in Nereis diversicolor, Mytilus galloprovincialis and Scrobicularia plana collected at different sites.

\begin{tabular}{|c|c|c|c|c|c|c|c|}
\hline Species & Location & $\begin{array}{c}\mathrm{SOD} \\
\left(\mathrm{U} \mathrm{m}^{-1} \mathrm{TP}\right)\end{array}$ & $\begin{array}{c}\text { CAT } \\
(\mu \mathrm{mol} \mathrm{min} \\
\left.\mathrm{mg}^{-1} \mathrm{TP}\right)\end{array}$ & $\begin{array}{l}\text { GPX-T } \\
\text { (nmol min } \\
\left.\mathrm{mg}^{-1} \mathrm{TP}\right)\end{array}$ & $\begin{array}{c}\mathrm{MT} \\
\left(\mathrm{mg} \mathrm{g}^{-1} \mathrm{TP}\right)\end{array}$ & $\begin{array}{c}\mathrm{LPO} \\
\left(\mu \mathrm{mol} \mathrm{g}{ }^{-1} \mathrm{TP}\right)\end{array}$ & References \\
\hline \multirow[t]{3}{*}{ Nereis diversicolor } & Seine estuary, France & & $15-98$ & & & & Durou et al. 2007a \\
\hline & Cádiz Bay, Spain & & $25-225$ & $36.9-42.1$ & $\begin{array}{l}8.7-15.5 \\
7.6-24.7\end{array}$ & & $\begin{array}{l}\text { Pérez et al. } 2004 \\
\text { Solé et al } 2009\end{array}$ \\
\hline & $\begin{array}{l}\text { west coast of Portugal } \\
\text { Oued Souss, Morrocco }\end{array}$ & $15-45$ & $\begin{array}{c}19-25 \\
16.9-87.9\end{array}$ & $7-15$ & & $0.5-1.2$ & $\begin{array}{l}\text { Moreira et al. } 2006 \\
\text { Ait Alla et al. } 2006\end{array}$ \\
\hline M. galloprovincialis & south coast of Portugal & $6-19$ & $35-60$ & $4-8$ & $5-17$ & $1-14$ & Cravo et al. 2009 \\
\hline \multirow[t]{2}{*}{ Scrobicularia plana } & south coast of Portugal & $117.9-132.3$ & $14.3-249.4$ & $3.3-20.3$ & $0.2-4.3$ & $0.1-0.97$ & Data not published \\
\hline & Cádiz Bay, Spain & 8.9-28.1 & 136.7-269.7 & $19.4-45.3$ & $2.0-7.7$ & $0.2-4.1$ & Data not published \\
\hline
\end{tabular}

The enzymatic results from this study are in the same range as those reported for the same species in Cádiz Bay (Pérez et al. 2004, Solé et al. 2009), on the west coast of Portugal (Moreira et al. 2006), in the Seine estuary in France (Durou et al. 2007a) and in the Oued Souss in Morocco (Ait Alla et al. 2006) (Table 2). In the Guadiana River and Ria Formosa Lagoon, CAT, SOD and GPX activities were similar to the ones reported for bivalves Mytilus galloprovincialis (Cravo et al. 2009) and Scrobicularia plana (data not published) (Table 2).

Besides their role in metal detoxification and homeostasis, MTs are also known as ROS scavengers (Langston et al. 1998, Viarengo et al. 1999). The MT concentrations in polychaetes from the Ria Formosa Lagoon and the Guadiana River were higher than in polychaetes from Cádiz Bay. Although polychaetes from the Guadiana River and the River Formosa Lagoon also showed high concentrations of $\mathrm{Cu}, \mathrm{Ni}$ and $\mathrm{Pb}$, the general response of MTs did not reflect the overall metal concentrations present in polychaetes from all the sites sampled. The lack of MT induction after metal exposure in polychaete species has also been reported by other authors (Poirier et al. 2006, Solé et al. 2009), and could be related to the presence of other physiological detoxification mechanisms in polychaetes to cope with high metal concentrations, such as storage of insoluble metals in detoxification granules, increases in mucus secretion, accumulation in specific body parts and tissues and exocytosis (Gibbs et al. 2000, Berthet et al. 2003, Mouneyrac et al., 2003). There was a significant relationship between MT and Ni (correlation analysis and CCA), reflecting the MT action in detoxifying the higher Ni concentrations found in the Guadiana River and the Ria Formosa Lagoon (A-RF). Nickel can generate ROS, leading to alterations in the cellular antioxidant system (Wang and Rainbow 2005, Moreira et al. 2006, Valavanidis et al. 2006) and MT may act as an ROS scavenger, detoxifying the excess of ROS originated by this metal and preventing further oxidative damage in polychaete tissues. The presence of this metal at these two sites is associated with freshwater inputs that lead to a higher Ni availability in sediments and consequently to a higher accumulation by polychaetes. Other study showed high degrees of
$\mathrm{Ni}$ accumulation in polychaete tissues associated with high Ni concentrations in interstitial water due to the oxidation of metal sulphides present in the sediment (Pesch et al. 1995, Otero et al. 2000, Ruus et al. 2005).

The MT levels in $N$. diversicolor from this study were lower than those reported by Pérez et al. (2004) and Solé et al. (2009) in Cádiz Bay (Table 2), where no relationship between metals and MT levels was found. MTs were also in the range of those obtained in bivalves S. plana (data not published) and M. galloprovincialis (Cravo et al. 2009) collected at the same sites in both the Guadiana River and Ria Formosa Lagoon (Table 2).

When ROS production exceeds antioxidant defences, oxidative stress occurs, which causes membrane lipid peroxidation, among other effects (Matés 2000, Livingstone 2001, Viarengo et al. 2007). In the present study, LPO levels were, as for the antioxidant enzymes, site specific and higher in polychaetes from Cádiz Bay. The higher enzymatic activities and lipid peroxidation detected suggest that these antioxidant enzymes were unable to eliminate ROS and prevent deleterious effects in lipids of cellular membranes, originated by the higher cadmium concentration at these sites (Winston and Di Giulio et al. 1991, Matés 2000). CCA and correlation analysis showed an association between SOD and CAT activities, LPO levels and cadmium concentrations.

Few field studies report the presence of lipid peroxidation in polychaete species. The LPO levels in polychaetes from the southwest Iberian coast are similar to those reported by Moreira et al. (2006) for the west coast of Portugal from both clean and impacted sites (Table 2). In comparison to bivalve species, the levels are similar to the ones in S. plana collected from the same sites in the Guadiana River, Ria Formosa Lagoon and Cádiz Bay (data not published) and in the same range as the ones in M. galloprovincialis from the Ria Formosa Lagoon and Guadiana River (Table 2).

A specific biomarker for lead exposure should have been included in the multibiomarker approach used in this study, specifically the enzyme $\delta$-aminolevulinic acid dehydratase (ALAD), since this metal does not induce MT. This enzyme has been shown to be a potential biomarker for $\mathrm{Pb}$ contamination with several 
bivalve species from the Gulf of Cádiz to the Ria Formosa Lagoon (Company et al. 2011).

The fluctuation in biomarker levels in polychaetes from each site reflects not only the differences between metal loads, but also the interactions between mixtures of contaminants. The presence of complex mixtures of metals and other contaminants in these ecosystems is well recognized, with interactions that are reflected in the biomarker response of polychaetes (Kennish 2002, Sun and Zhou 2008, Cravo et al. 2009, Solé et al. 2009).

In conclusion, $N$. diversicolor showed different responses at the different sites along the southwest coast of the Iberian Peninsula, which suggests different sources and/or magnitudes of contamination in association with diverse anthropogenic activities. Although the metal concentrations found in $N$. diversicolor tissues are indicative of a low or moderate level of contamination, the applied biomarkers responded efficiently to specific site differences, except for MT, which did not reflect the overall metal concentrations present. The selected biomarkers can be integrated into future environmental quality assessments of the southwest Iberian coast, along with more specific biomarkers of metal exposure, such as ALAD $(\mathrm{Pb})$, or other physiological detoxification mechanisms specific to polychaetes. For these species, MT can also be included as a biomarker for oxidative stress but not a biomarker for metal exposure. The particular features of $N$. diversicolor evidence its role as a sentinel species, validating its capacity to bioaccumulate several metals from sediments.

\section{ACKNOWLEDGEMENTS}

We would like to thank the Interreg III-A Program for funding the projects RED CONTAMAR and PROTEOBIOMAR.

\section{REFERENCES}

Ait Alla A., Mouneyrac C., Durou C., Moukrim A., Pellerin, J. 2006. Tolerance and biomarkers as useful tools for assessing environmental quality in the Oued Souss estuary (Bay of Agadir, Morocco). Comp. Biochem. Physiol. C. 143: 23-29.

Almeida C., Serôdio P., Florêncio M.H., Nogueira J.M.F. 2007. New strategies to screen for endocrine-disrupting chemicals in the Portuguese marine environment utilizing large volume injection-capillary gas chromatography-mass spectrometry combined with retention time locking libraries (LVI-GC-MSRTL). Anal. Bioanal. Chem. 387: 2569-2583.

Amiard J., Geffard A., Amiard-Triquet C., Crouzet C. 2007. Relationship between the lability of sediment-bound metals $(\mathrm{Cd}, \mathrm{Cu}$, $\mathrm{Zn}$ ) and their bioaccumulation in benthic invertebrates. Estuar. Coast. Shelf Sci. 72: 511-521.

Bebianno M.J., Langston W.J. 1989. Quantification of metallothioneins in marine invertebrates using differential pulse polarography. Port. Electrochim. Acta 7: 59-64.

Bebianno M.J. 1995.Effects of pollutants in the Ria Formosa Lagoon, Portugal. Sci. Total Environ. 171: 107-115.

Berthet B., Mouneyrac C., Amiard J.C., Amiard-Triquet C., Berthelot Y., Le Hen A., Mastain O., Rainbow P.S., Smith B.D. 2003 Accumulation and soluble binding of cadmium, copper, and zinc in the polychaete Hediste diversicolor from coastal sites with different trace metal bioavailabilities. Arch. Environ. Contam. Toxicol. 45: 468-478.

Blasco J., Sáenz V., Gómez-Parra A. 2000. Heavy metal fluxes at the sediment - water interface of three coastal ecosystems from south-west of the Iberian Peninsula. Sci. Total Environ. 247: 189-199.

Blasco J., Gomes T., Garcia-Barrera T., Rodriguez-Romero A., Gonzalez-Rey M., Moran-Roldan F., Tromibini C., Miotk M., Gomez-Ariza J.L., Bebianno M.J. 2010. Metal occurrence in recent sediments from the southwest of the Iberian Peninsula. Sci. Mar. 74S1(1): 99-106.

Bocchetti R., Fattorini D., Gambi M.C., Regoli F. 2004. Trace metal concentrations and susceptibility to oxidative stress in the polychaete Sabella spallanzanii (Gmelin) (Sabellidae): potential role of antioxidants in revealing stressful environmental conditions in the Mediterranean. Arch. Environ. Contam. Toxicol. 46: 353-361.

Boski T., Moura D.M., Machado L.M., Bebianno M.J. 1999. Trace metals on the Algarve coast, I: Associations, origings and remobilization of natural components. Bul. Inst. Esp. Oceanogr. 15(1-4): 457-463.

Caetano M., Vale C., Falcão, M. 2006. Particulate trace metal distribution in Guadiana estuary punctuated by flood episodes. Estuar. Coast. Shelf Sci. 70: 109-116.

Cajaraville M.P., Bebianno M.J., Blasco J., Porte C., Sarasquete C., Viarengo A. 2000. The use of biomarkers to assess the impact of pollution in coastal environments of the Iberian Peninsula: a practical approach. Sci. Total Environ. 247: 295-311.

Carrasco M., López-Ramírez J.A., Benavente J., López-Aguayo F., Sales D. 2003. Assessment of urban and industrial contamination levels in the bay of Cádiz, SW Spain. Mar. Pollut. Bull. 46: 335-345.

Coelho M.R., Bebianno M.J., Langston M.J. 2002. Organotin levels in the Ria Formosa lagoon, Portugal. Appl. Organometal. Chem. 16: 384-390.

Company R., Serafim A., Lopes B., Cravo A., Shepherd T.J., Pearson G., Bebianno M.J. 2008. Using biochemical and isotope geochemistry to understand the environmental and public health implications of lead pollution in the lower Guadiana River, Iberia: A freshwater bivalve study. Sci. Total Environ. 405: 109-119.

Company R., Serafim A., Lopes B., Cravo A., Kalman J., Riba I., DelValls T.A., Blasco J., Delgado J., Sarmiento A.M., Nieto J.M., Shepherd T.J., Nowell G., Bebianno M.J. 2011. Source and impact of lead contamination on -aminolevulinic acid dehydratase activity in several marine bivalve species along the Gulf of Cádiz. Aquat. Toxicol. 101: 146-154.

Cravo A., Madureira M., Felícia H., Rita F., Bebianno M.J. 2006. Impact of outflow from the Guadiana River on the distribution of suspended particulate matter and nutrients in the adjacent coastal zone. Estuar. Coast. Shelf Sci. 70: 63-75.

Cravo A., Lopes B., Serafim A., Company R., Barreira L., Gomes T., Bebianno M.J. 2009. A multibiomarker approach in Mytilus galloprovincialis to assess environmental quality. J. Environ. Monit. 11: 1673-1686.

Díez G., Soto M., Canton L., Vaquero C., Marigomez I. 2000. Hediste (Nereis) diversicolor as bioindicator of metal and organic chemical bioavailability: A field study. Ecotoxicol. Environ. Restor. 3: 7-15.

Dionísio L.P.C., Rheinheimer G., Borregos J.J. 1999. Microbial pollution in the Ria Formosa (South of Portugal). Mar. Pollut. Bull. 40(2): 186-193.

Douhri H., Sayah F. 2009. The use of enzymatic biomarkers in two marine invertebrates Nereis diversicolor and Patella vulgate for the biomonitoring of Tangier's bay (Morocco). Ecotoxicol. Environ. Saf. 72: 394-399.

Durou C., Poirier L., Amiard J.-C., Budzinski H., Gnassia-Barelli M., Lemenach K., Peluhet L., Mouneyrac C., Rómeo M., Amiard-Triquet C. 2007a. Biomonitoring in a clean and a multi-contaminated estuary based on biomarkers and chemical analyses in the endobenthic worm Nereis diversicolor. Environ. Pollut. 148: 445-458.

Durou C., Smith B., Roméo M., Rainbow P., Mouneyrac C., Mouloud M., Gnassia-Barelli M., Gillet P., Deutsch B., AmiardTriquet C. 2007b. From biomarkers to population responses in Nereis diversicolor: Assessment of stress in estuarine ecosystems. Ecotoxicol. Environ. Saf. 66: 402-411. 
Durou C., Mouneyrac C., Amiard-Triquet C. 2008. Environmental quality assessment in estuarine ecosystems: Use of biometric measurements and fecundity of the ragworm Nereis diversicolor (Polychaeta, Nereididae). Water Res. 42: 2157-2165.

Erdelmeier I., Gerard-Monnier D., Yadan J.C., Acudiere J. 1998. Reactions of N-methyl-2-phenylindole with malondialdehyde and 4-hydroxyalkenals. Mechanistic aspects of the colorimetric assay of lipid peroxidation. Chem. Res. Toxicol. 11: 1184-94.

Ferreira-Cravo M., Piedras F.R., Moraes T.B., Ferreira J.L.R., de Freitas D.P.S., Machado M.D., Geracitano L.A., Monserrat J.M. 2007. Antioxidant responses and reactive oxygen species generation in different body regions of the estuarine polychaete Laeonereis acuta (Nereididae). Chemosphere. 66: 1367-1374.

Geracitano L.A., Bocchetti R., Monserrat J.M., Regoli F., Bianchini A. 2004. Oxidative stress responses in two populations of Laeonereis acuta (Polychaeta, Nereididae) after acute and chronic exposure to copper. Mar. Environ. Res. 58: 1-17.

Gibbs P.E., Burt G.R., Pascoe P.L., Llewellyn C.A., Ryan K.P. 2000. Zinc, copper and chlorophyll-derivatives in the polychaete Owenia fusiformis. J. Mar. Biol. Assoc. U.K. 80: 235-248.

Gillet P., Mouloud M., Durou C., Deutsch B. 2008. Response of Nereis diversicolor population (Polychaeta, Nereididae) to the pollution impact - Authie and Seine estuaries (France). Estuar. Coast. Shelf Sci. 76: 201-210.

Greenwald R.A. 1985. Handbook of methods for oxygen radical research. CRC Press, Boca Raton, FL, 464 pp.

Kalman J., Riba I., Blasco J., DelValls T.A. 2008. Is $\delta$-aminolevulinic acid dehydratase activity in bivalves from south-west Iberian Peninsula a good biomarker of lead exposure? Mar. Environ. Res. 66(1): 38-40.

Kennish M.J. 2002. Environmental threats and environmental future of estuaries. Environ. Conserv. 29(1): 78-107.

Langston W.J, Bebianno M.J., Burt G.R. 1998. Metal handling strategies in molluscs. In: Langston W.J. and Bebianno M.J. (eds.), Metal Metabolism in Aquatic Environments. Chapman and Hall, London, pp. 219-283.

Lawrence R.A., Burk R.F. 1976. Glutathione peroxidase activity in selenium-deficient rat liver. Biochem. Biophy. Res. Commun. 71: $952-958$

Livingstone D.R. 2001. Contaminated-stimulated reactive oxygen species production and oxidative damage in aquatic organisms. Mar. Pollut. Bull. 42: 656-666.

Lowry O.H., Rosenbrough N.J., Farr A.L., Randall R.J. 1951. Protein measurement with the Folin phenol reagent. J. Biol. Chem. 193: 265-275.

Machado L.M., Bebianno M.J., Boski T., D.M. Moura. 1999. Trace metals on the Algarve coast, II: Bioaccumulation in mussels Mytilus galloprovincialis (Lamarck, 1819). Bol. Inst. Esp. Oceanogr. 15(1-4): 465-471.

Matés J.M. 2000. Effects of antioxidant enzymes in the molecular control of reactive oxygen species toxicology. Toxicol. 153: 83-104.

McCord J.M., Fridovich I. 1969. Superoxide dismutase: an enzymatic function for erythrocuprein (hemocuprein). J. Biol. Chem. 244(22): 6049-6955.

Moreira S.M., Lima I., Ribeiro R., Guilhermino L. 2006. Effects of estuarine sediment contamination on feeding and on key physiological functions on the polychaete Hediste diversicolor: Laboratory and in situ assays. Aquat. Toxicol. 78: 186-201.
Mouneyrac C., Mastain O., Amiard J.C., Amiard-Triquet C., Beaunier P., Jeantet A.-Y., Smith B.D., Rainbow P.S. 2003. Trace metal detoxification and tolerance of the estuarine worm $\mathrm{He}$ diste diversicolor chronically exposed in their environment. Mar. Biol. 143: 731-744.

Mudge S.M., Bebianno M.J. 1997. Sewage contamination following an accidental spillage in the Ria Formosa, Portugal. Mar. Pollut. Bull. 34(3): 163-170.

Otero X.L., Sanchez J.M., Macias F. 2000. Bioaccumulation of heavy metals in thionic fluvisols by a marine polychaete: the role of metal sulfides. J. Environ. Qual. 29: 1133-1141.

Pérez E., Blasco J., Solé M. 2004. Biomarker responses to pollution in two invertebrate species: Scrobicularia plana and Nereis diversicolor from the Cádiz bay (SW Spain). Mar. Environ. Res. 58: 275-279.

Pesch C.E., Hansen D.J., Boothman W.S., Berry W.J., Mahony J.D. 1995. The role of acid-volatile sulfide and interstitial water metal concentrations in determining bioavailability of cadmium and nickel from contaminated sediments to the marine polychaete Neanthes arenaceodentata. Environ. Toxicol. Chem. 14: 129-141.

Poirier L., Berthet B., Amiard, J.C., Jeantet A.Y., Amiard-Triquet C. 2006. A suitable model for the biomonitoring of trace metal bioavailabilities in estuarine sediments: the annelid polychaete Nereis diversicolor. J. Mar. Biol. Ass. U.K. 86: 71-82.

Ruus A., Schaaning M., Øxnevad S., Hylland K. 2005. Experimental results on bioaccumulation of metals and organic contaminants from marine sediments. Aquat. Toxicol. 72: 273-292.

Solé M., Kopecka-Pilarczyk J., Blasco J. 2009. Pollution biomarkers in two estuarine invertebrates, Nereis diversicolor and Scrobicularia plana, from a Marsh ecosystem in SW Spain. Environ. Int. 35(3): 523-531.

Sun F., Zhou Q. 2008. Oxidative stress biomarkers of the polychaete Nereis diversicolor exposed to cadmium and petroleum hydrocarbons. Ecotoxicol. Environ. Saf. 70: 106-114.

Valavanidis A., Vlahogianni T., Dassenakis M., Scoullos M. 2006. Molecular biomarkers of oxidative stress in aquatic organisms in relation to toxic environmental pollutants. Ecotox. Environ. Saf. 64: 178-189.

Viarengo A., Burlando B., Dondero F., Marro A., Fabbri R. 1999. Metallothionein as a tool in biomonitoring programmes. Biomarkers 4: 455-466.

Viarengo A., Lowe D., Bolognesi C., Fabbri E., Koehler A. 2007. The use of biomarkers in biomonitoring: A 2-tier approach assessing the level of pollutant-induced stress syndrome in sentinel organisms. Comp. Biochem. Physiol. C 146: 281-300.

Wang W.-X., Rainbow P.S. 2005. Influence of metal exposure history on trace metal uptake and accumulation by marine invertebrates. Ecotoxicol. Environ. Saf. 61: 145-159.

Winston G.W., Di Giulio R.T. 1991. Prooxidant and anti- oxidant mechanisms in aquatic organisms. Aquat. Toxicol. 19: 137-161.

Zhou Q.X., Rainbow P.S., Smith B.D. 2003. Tolerance and accumulation of the trace metals zinc, copper and cadmium in three populations of the polychaete Nereis diversicolor. J. Mar. Biolog. Assoc. U.K. 83: 65-72.

Received April 18, 2011. Accepted September 30, 2011. Published online January 7, 2013. 